\title{
Cell viability in natural phytoplankton communities quantified by a membrane permeability probe
}

\author{
Susana Agustí ${ }^{1}$ and M. Carmen Sánchez \\ Instituto Mediterráneo de Estudios Avanzados, CSIC-UIB, Miquel Marqués 21, 07190 Esporles, Mallorca, Spain
}

\begin{abstract}
A nonstaining method, based on the digestion of dead cells, the membranes of which are permeable when exposed to an enzymatic cocktail (DNAse I and Trypsin), was used to identify living cells in cultured and natural phytoplankton populations. The cell digestion method was applied to cultures of nine phytoplankton species, encompassing a broad taxonomic range. The percentage of living cells obtained with the enzymatic digestion test was found to be consistent with that obtained with the vital stain fluorescein diacetate, which could be applied to only six of the species used. Use of the cell digestion method showed the phytoplankton community viability in Blanes Bay (NW Mediterranean littoral) to be very low at the beginning of the summer (34\% and $31 \%$ of diatoms and cyanobacteria cells were alive, respectively), when oligotrophic conditions prevailed. The phytoplankton viability increased slightly by midsummer, with the entire cyanobacteria population, which dominated the community, composed of living cells, and most $(81 \%)$ of the diatom cells were living in the fall. The patterns in cell viability revealed by the cell digestion method were consistent with the seasonal variability in phytoplankton lysis rates and the shifting contribution of different groups to the phytoplankton community.
\end{abstract}

Recent reports point to phytoplankton cell death and subsequent lysis as an important, albeit neglected, process in the ocean (Brussaard et al. 1995; Agustí et al. 1998; Kirchman 1999; Agustí and Duarte 2000; Agustí et al. 2001). Cell lysis was found to be the main cause for the collapse of a Phaeocystis bloom in the North Sea (van Boekel et al 1992; Brussard et al. 1995) and the development of a mucilage event in the Adriatic Sea (Baldi et al. 1997). High lysis rates have been reported for summer Mediterranean phytoplankton, both in oceanic (Agustí et al. 1998) and coastal waters (Agustí and Duarte 2000), and in the subtropical Atlantic (Agustí et al. 2001). A corollary of these reports is that an important fraction of phytoplankton cells must be compromised or dying whenever lysis rates are important.

The identification of damaged cells has been prevented by the lack of appropriate methods to reliably discriminate living from dead or compromised cells in natural phytoplankton communities. The presence of empty silicon valves has been used to identify dead diatom cells (e.g., Knoechel and Kalff 1978). This method, restricted to diatoms, provides a minimum estimate of the damaged cells in the community, for it does not consider dying cells that still conserve cellular contents. As a result, most reports of cell lysis in natural phytoplankton communities have not assessed directly the status of the cells and provide little or no information on the impact of cell death on the different populations present in

\footnotetext{
${ }^{1}$ Corresponding author (sagusti@uib.es).
}

\section{Acknowledgments}

This is a contribution to the project COMWEB (European Commission contract number MAS3-CT96-0045), and grants from the Spanish Commission of Science and Technology (CICYT MAR981676-E and REN2000-1471-CO2-01). We thank E. Benavent, O. Moreno., O. Robledo, V. S. Parada, and S. López for sampling and laboratory assistance and to S. V. Loureiro for fun and help with flow cytometry application. We are grateful to C. M. Duarte and two anonymous reviewers for valuable comments on the manuscript. the communities (e.g., van Boekel et al. 1992; Agustí et al. 1998). Whether dead phytoplankton cells comprise an important proportion of phytoplankton communities and how they are distributed among the different taxa remain, therefore, unexplored.

Loss of the ability to maintain homeostasis, resulting in increased membrane permeability, characterizes dead (necrotic and advanced apoptotic) cells (Wyllie et al. 1980; Ellis et al. 1991; Darzynkiewicz et al. 1994). Cell membrane permeability tests have, therefore, been developed for the discrimination between living and dead cells (Wyllie et al. 1980; Ellis et al. 1991; Darzynkiewicz et al. 1994). Techniques based on vital stains have also been used to identify living versus dead cells, including phytoplankton (e.g., Selvin et al. 1989; Lee and Rhee 1997). However, vital fluorescent stains have been rarely applied for the identification of living cells in natural phytoplankton communities (but see Veldhuis and Kraay 2000) due to (1) difficulties in the identification of the stained cells within mixed assemblages, including both autotrophic and heterotrophic cells, (2) ambiguities in establishing the threshold staining intensities that best separate live from dead cells in the continuum from brightly stained to unstained cells, and (3) interference between stain fluorescence and autofluorescence (e.g., by chlorophyll) of phytoplankton cells. These difficulties could be circumvented by the use of a nonstaining membrane permeability probe to discriminate living versus dead cells. This study tests the applicability of a nonstaining cell membrane permeability test, the cell digestion method (Darzynkiewicz et al. 1994), as a probe to discriminate and identify living versus dead cells in natural phytoplankton communities.

\section{Methods}

Application of the cell digestion assay (cell membrane permeability probe) to phytoplankton cultures-Living and dead phytoplankton cells were discriminated using a modi- 
fied cell membrane permeability test, originally described by Darzynkiewicz et al. (1994). The test is based on the brief exposure of the cells to the enzymes Trypsin and DNAse I, which enter the cytoplasm of cells with damaged plasma membranes (i.e., necrotic or advanced apoptotic cells) resulting in the entire digestion of the cells, while having little or no effect on the viability, morphology or function of live cells (Darzynkiewicz et al. 1994). The digestion of dead cells is based on the fragmentation and hydrolysis of DNA by DNAse I, and phospholipid hydrolysis by Trypsin, which penetrate the damaged cells. The digested dead cells are undetectable by microscopic observation and lose any fluorescence signals (both autofluorescence and staining), and are, therefore, effectively removed from the population.

Viability tests by the cell digestion method were made on cells from nine marine phytoplankton species (Chlorella sp., Dunaliella sp., Emiliania huxleyi, Heterocapsa sp., Phaeocystis sp., Phaeodactyllum tricornutum, Synechococcus sp., Thalassiosira sp., and Prochlorococcus marina CCMP 1378). The cultures were grown in $\mathrm{f} / 2$ medium at $18^{\circ} \mathrm{C}$ (except Prochlorococcus marina and Synechococcus sp., which were grown at $21^{\circ} \mathrm{C}$ ) and under continuous illumination of $70 \mu \mathrm{mol}$ photons $\mathrm{m}^{-2} \mathrm{~s}^{-1}$. Prochlorococcus marina was grown in PC medium (Provasoli-Guillard CCMP media recipes) under an illumination of $30 \mu \mathrm{mol}$ photons $\mathrm{m}^{-2} \mathrm{~s}^{-1}$, which enhanced their pigment content, improving their detection by flow cytometry.

In the original method (Darzynkiewicz et al. 1994) cells were concentrated by centrifugation and washed in HBSS (Hanks' Balanced Salts) medium. However, this procedure was found to cause a loss of between 15 to $30 \%$ of the phytoplankton cells. To avoid this loss, the enzyme solutions were added directly to the sample, which ensured no cell loss while yielding similar percent cell viability as that obtained using the original procedure. This was tested for cultures of Thalassiosira sp. $(101 \% \pm 3.6$ and $100 \% \pm 0.7$ of alive cells obtained by the original and the modified procedures, respectively) Phaeocystis sp. $(85 \% \pm 3.7$ and $88.8 \%$ \pm 1.2 of alive cells obtained by the original and the modified procedures, respectively) and Emiliania huxleyi $(95 \% \pm 11$ and $91.5 \% \pm 1$ of alive cells obtained by the original and the modified procedure, respectively).

Stock solutions of DNAse I (800 $\mu \mathrm{g} \mathrm{ml}^{-1}$ in HBSS), Trypsin (2\% in HBSS), and Trypsin inhibitor $\left(5.8 \mathrm{mg} \mathrm{ml}^{-1}\right)$ were prepared in HBSS medium (Sigma) following Darzynkiewicz et al. (1994) and kept frozen at $-25^{\circ} \mathrm{C}$ until use. The cell digestion method was tested by adding $200 \mu \mathrm{l}$ of DNAse I solution to a 1-ml culture sample, followed by incubation for $15 \mathrm{~min}$ at $37^{\circ} \mathrm{C}$. Then, $200 \mu \mathrm{l}$ of Trypsin solution were added, followed by incubation for an additional $30 \mathrm{~min}$ at $37^{\circ} \mathrm{C}$ (Darzynkiewicz et al. 1994). At the end of the incubation, $0.6 \mathrm{ml}$ of Trypsin inhibitor solution were added (in the proportion one unit of trypsin inhibitor per unit of trypsin in the sample). Duplicated culture samples to be used as blanks were incubated for the same time and temperature with the same additions of HBSS medium instead of the enzyme cocktail.

The cells remaining after the enzymatic treatment, i.e., those having intact membranes, were considered to represent living or viable cells, whereas dead ones, with compromised membranes, were digested out by the enzymatic cocktail and were undetectable under the microscope. The percentage of viable cells in the culture was calculated by dividing the concentration of viable cells after the enzyme treatment, determined under an inverted microscope or using flow cytometry, by the cell concentration in the blanks, which represent the total (dead plus living) cell concentration. The number of dead cells was calculated by subtracting the number of living cells from the total cell abundance.

Samples for microscopic enumeration were filtered, at the end of the assays, onto black polycarbonate filters, or placed in a hematocytometer or microscopic cubette, for the quantification of cell concentration under an inverted microscope. Samples for determination of cell abundance using flow cytometry were counted in a FACSCalibur Flow Cytometer (Beckton Dickinson) fitted with a $488 \mathrm{~nm}$ laser and a photomultiplier for forward-scattered light detection. An aliquot of a calibrated solution of $1-\mu \mathrm{m}$ diameter high-green fluorescent beads (Polysciences Inc.) added to the samples was used as an internal standard for the quantification of cell concentration. The red, green, and orange fluorescence emissions and the forward and side scattering of the cells and beads were used to detect different cell populations and to differentiate them from the fluorescent beads. The HBSS medium used to prepare the reagents as described above developed a red color, which interfered with the observations and was, therefore, replaced by HBSS without phenol red (H-1387, Sigma). The trypsin inhibitor solution added to end the incubation produced crystals that interfered with flow cytometry signals, so that the enzyme reaction was stopped by placing the samples on ice. We tested that the last procedure had no impact in the cell counts for the species used. However, the possibility of cell damage when using ice to stop the reaction should be checked for other species, since we have observed that some species (e.g., large diatoms) are sensitive to this procedure.

The effects of the incubation temperature and the incubation time in the efficiency of the digestion of dead cells were tested by incubating duplicate samples of Chlorella sp., Dunaliella sp., Heterocapsa sp., Phaeocystis sp., Phaeodactyllum tricornutum, Synechococcus sp., and Thalassiosira sp. cultures at $37^{\circ} \mathrm{C}$ and $20^{\circ} \mathrm{C}$ and by varying the incubation time from $45 \mathrm{~min}$ to 90 and $135 \mathrm{~min}$, respectively. The effect of the enzyme concentration on the digestion of dead cells was tested by adding a variable concentration of DNAse I and Trypsin to the samples. Seven final concentrations of DNAse I (final concentrations 0 to $271.4 \mu \mathrm{g} \mathrm{ml}^{-1}$ ) and Trypsin (final concentrations 0 to $7.14 \mathrm{mg} \mathrm{ml}^{-1}$ ) were added each, as 200- $\mu$ l solutions, to duplicate $1-\mathrm{ml}$ aliquots of Chlorella sp., Emiliania huxleyi, Heterocapsa sp., Phaeocystis sp., Synechococcus sp., and Thalassiosira sp. cultures, which were then processed as described above. All the tests described were conducted with aged cultures, which are likely to contain a higher fraction of dead cells (e.g., Selvin et al. 1989; Myklestad 2000). This was tested through the examination of the evolution of the fraction of living and dead cells during population growth, using cultures of Thalassiosira sp., Prochlorococcus marina, Phaeocystis sp., and Synechococcus sp. sampled, in duplicate, along the exponential and stationary phases. 
Table 1. The percentage of living cells (mean \pm SE) in different phytoplankton cultures examined at the stationary phase, as obtained by the enzymatic cell digestion (DNAse I and Trypsin) test of membrane permeability and after exposure to the vital stain FDA. Dash indicates FDA test could not be applied to the species. Data in parentheses show the exponential growth phase for some of the species.

\begin{tabular}{|c|c|c|}
\hline Species & $\begin{array}{c}\text { Cell } \\
\text { digestion } \\
\text { (\% living } \\
\text { cells })\end{array}$ & $\begin{array}{c}\text { FDA } \\
\text { (\% living } \\
\text { cells) }\end{array}$ \\
\hline Synechococcus sp. & 88.4 & - \\
\hline Phaeodactyllum tricornutum & 78.8 & - \\
\hline Prochlorococcus marina & 64.5 & - \\
\hline Chlorella sp. & $70 \pm 2.7$ & $81 \pm 3.7$ \\
\hline Phaeocystis sp. & $68.9 \pm 2.8$ & $65.2 \pm 3.8$ \\
\hline Emiliania huxleyi & 92 & 93 \\
\hline Heterocapsa sp. & $61.6 \pm 1.5$ & $63.1 \pm 0.8$ \\
\hline $\begin{array}{l}\text { Dunaliella sp. } \\
\text { (Exponential growth phase) }\end{array}$ & $\begin{array}{l}88.9 \pm 4.2 \\
(100)\end{array}$ & $\begin{array}{c}87.2 \pm 1.85 \\
(100)\end{array}$ \\
\hline $\begin{array}{l}\text { Thalassiosira sp. } \\
\text { (Exponential growth phase) }\end{array}$ & $\begin{array}{l}84 \pm 2.7 \\
(100)\end{array}$ & $\begin{array}{c}76.4 \pm 4.9 \\
(100)\end{array}$ \\
\hline
\end{tabular}

The results from the cell digestion analysis were compared with those obtained using the vital stain Fluorescein diacetate (FDA), a substrate for the intracellular enzymes esterases. The product of FDA hydrolysis, fluorescein, yields a high-green florescence when excited with blue light. FDA is hydrolyzed upon penetrating viable cells, leading to the accumulation of fluorescein within live cells, which is not possible in cells with compromised membranes (Rotman and Papermaster 1966). Thus, living cells, those containing fluorescein, show bright green fluorescence when illuminated by blue light, whereas dead cells, with damaged cell membranes, only show pigment autofluorescence. This comparison could only be made on the species that showed a clear stain with FDA (Chlorella sp., Dunaliella sp., Emiliania huxleyi, Heterocapsa sp., Phaeocystis sp., and Thalassiosira sp.), among those used in this study (Table 1). Triplicate 1$\mathrm{ml}$ samples from phytoplankton cultures in stationary phase received 20 to $80 \mu \mathrm{l}$, depending on the species, of a $1 \mathrm{mg}$ $\mathrm{ml}^{-1}$ solution of FDA in $100 \%$ acetone. The concentration of living (green fluorescent) and dead cells (only autofluorescent) was determined within 10-20 min of staining under epifluorescence microscopy. Parallel triplicate 1-ml samples were used to estimate the fraction of living and dead cells using the cell digestion method. Owing to an accidental loss, only one set of samples could be processed for Emiliania huxleyi.

Application of the cell digestion assay to natural coastal NW Mediterranean phytoplankton communities-The use of the cell digestion method to quantify the proportion of living and dead phytoplankton cells in natural phytoplankton communities was demonstrated in samples from Blanes Bay (NW Mediterranean Sea). Phytoplankton communities in Blanes Bay have been shown to undergo high lysis rates in summer, declining toward the fall (Agustí and Duarte 2000). We sampled the surface waters in Blanes Bay at 2-week intervals between January and November 1998, parallel to the determination of a number of properties included in a monitoring study of Blanes Bay (Duarte et al. 1999).

Chlorophyll $a$ (Chl $a$ ) concentration was measured fluorometrically in samples concentrated on Whatman GF/F filters and extracted in 90\% acetone, as described in Agustí and Duarte (2000). Phytoplankton lysis rates were measured following the dissolved esterase activity method described in Agustí et al. (1998). In short, after sampling, $50 \mu \mathrm{l}$ of EDTA and $50 \mu$ l of FDA (Sigma) were added to triplicated 5-ml samples filtered through 0.2- $\mu \mathrm{m}$ Millipore Millex (to a final concentration of 0.2 and $0.02 \mathrm{mM}$, respectively) and mixed in a vortex mixer. After incubating the samples for an hour at $20^{\circ} \mathrm{C}$, the fluorescence emission was immediately measured in a Shimadzu RF-5000 spectrofluorometer at 451 $\mathrm{nm}$ and $510 \mathrm{~nm}$ excitation and emission (10 $\mathrm{nm}$ bandwidth) wavelengths, respectively. The particulate esterase activity (PEA), needed to estimate the lysis rate, was calculated from the measured $\mathrm{Chl} a$ concentration, using a ratio of particulate esterase activity to Chl $a$ ratio of $331 \mathrm{nmol}$ Fluorescein $(\mathrm{mg}$ Chl $a)^{-1} \mathrm{~h}^{-1}$ derived from phytoplankton cultures (Agustí et al. 1998). Nonenzymatic hydrolysis of FDA was corrected by subtracting the lowest value $\left(18 \mathrm{nmol}\right.$ Fluorescein $\mathrm{L}^{-1}$ $\mathrm{h}^{-1}$ ) of dissolved esterase activity (DEA) found during the study period from the measured DEA values. Phytoplankton cell lysis rates $\left(\mu_{\mathrm{L}} \mathrm{d}^{-1}\right)$ were calculated as the decrease in particulate esterase activity (PEA) with time $(t)$, due to the production of dissolved EA during cell lysis (Agustí et al. 1998). The production of dissolved EA was derived by combining the measured dissolved activity with estimates of the rate of loss of the activity of the enzyme calculated from water temperature (Agustí and Duarte 2000). The use of a constant particulate esterase activity to $\mathrm{Chl} a$ ratio has been estimated to introduce an error, due to seasonal variation in phytoplankton community structure, of about $13 \%$ of the estimated lysis rates (Agustí and Duarte 2000).

Samples for the quantification of living versus dead phytoplankton cells were analyzed monthly in June, July, August, October, and November. A variable volume of water (2-3 liters) was concentrated to $10-20 \mathrm{ml}$ by using a Millipore cell concentrator, fitted with a 5- $\mu \mathrm{m}$ net, for the quantification of phytoplankton cells larger than $5 \mu \mathrm{m}$. The cell digestion method was applied to duplicate 2-ml subsamples from the cell concentrate, after incubation with the enzymatic cocktail trypsin inhibitor was added. An additional 45 -ml subsample from the concentrate was fixed with glutaraldehyde (1\% final concentration) for the quantification of the total cell density in the different taxa. The samples were observed under an inverted microscope to estimate the concentration of living and total phytoplankton cells, respectively, identified to genera. To quantify the concentration of total and living cells in the small $(<5 \mu \mathrm{m})$ fraction of the phytoplankton community, a 20-ml sample was fixed with glutaraldehyde (1\% final concentration) and the cell digestion method applied to fresh duplicate 20-ml subsamples, respectively. The resulting samples were gently filtered onto $0.6-\mu \mathrm{m}$ pore size black Nuclepore filters, which were kept refrigerated and examined before $1 \mathrm{~h}$ under an epifluorescence microscope (Zeiss Axioplan) fitted with a blue light filter, and the autotrophic, red, and yellow-orange fluores- 


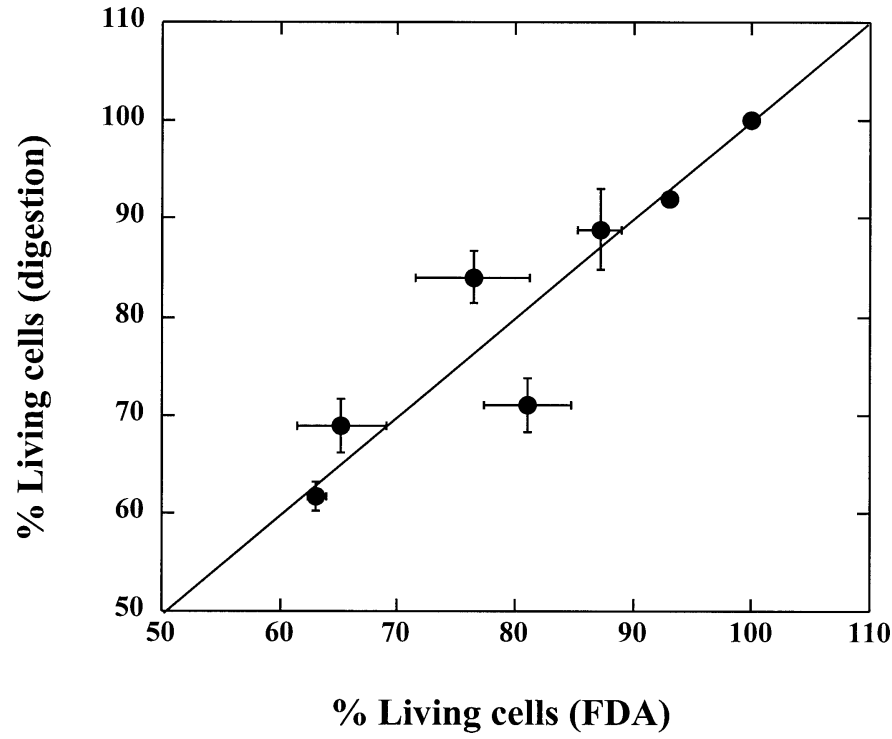

Fig. 1. The relationship between the percentage of living cells estimated by the cell digestion assay and that estimated using the vital stain FDA. The line represents the 1:1 line and the error bars represent \pm 1 standard deviation.

cent cells were differentiated into eukaryotic and cyanobacteria cells $(<5 \mu \mathrm{m})$, respectively. Parallel examination of natural samples using flow cytometry showed no evidence of the presence of Prochlorococcus along the study.

\section{Results}

Assessment of the cell viability in phytoplankton cultures-The percentage of cells remaining after the digestion of dead cells with the enzymatic (DNAse I and Trypsin) cocktail varied from $61.6 \%$ living cells at the stationary phase of Heterocapsa sp. to $100 \%$ living cells in the exponential growth phase of Thalassiosira sp. and Dunaliella sp. cultures (Table 1). The percent living cells estimated using the enzyme digestion method did not differ significantly $(t$ test) from that calculated using FDA staining (Table 1). There was a strong $(r=0.93, P<0.001)$ relationship between the percent living cells estimated using the cell digestion method and FDA staining, which did not deviate significantly from the $1: 1$ line (slope $=0.95 \pm 0.13$, Ho: slope $=1, P>0.05$; intercept $=4.61 \pm 11.08 \%$, Ho: intercept $=0, P>0.05 ; N=9)$, indicating the methods to yield unbiased estimates relative to one another (Fig. 1).

We did not appreciate, using transmitted light and epifluorescence microscopy, any evidence of morphological changes in the cells remaining after the incubation with the enzyme cocktail (i.e., living cells), and their form, color, and texture were similar to those of untreated cells. Their fluorescence signal was also similar to that observed in blank samples. The phytoplankton cells attacked by the enzymes were indeed totally digested during the assay, and there were no remaining cell fragments, other than some empty diatom valves, identifiable using transmitted light and epifluorescence microscopy.

The concentration of cells digested by the assay (dead
Table 2. The effect of incubation time on the living cell concentration (cell digestion assay) and total cell concentration (blank samples) of different species incubated at $37^{\circ} \mathrm{C}$ during $45 \mathrm{~min}$ (standard assay incubation time) and 90 and $135 \mathrm{~min}$.

\begin{tabular}{|c|c|c|c|}
\hline \multirow[b]{2}{*}{ Species } & \multicolumn{3}{|c|}{ Incubation time } \\
\hline & $\begin{array}{c}45 \mathrm{~min} \\
\left(\text { cells } \mathrm{ml}^{-1} \text { ) }\right.\end{array}$ & $\begin{array}{c}90 \mathrm{~min} \\
\left(\text { cells } \mathrm{ml}^{-1} \text { ) }\right.\end{array}$ & $\begin{array}{c}135 \mathrm{~min}^{-1} \\
\left(\text { cells } \mathrm{ml}^{-1} \text { ) }\right.\end{array}$ \\
\hline \multicolumn{4}{|l|}{ Synechococcus sp. } \\
\hline Blank & $1.38 \times 10^{7}$ & $1.37 \times 10^{7}$ & $1.50 \times 10^{7}$ \\
\hline Cell digestion & $8.62 \times 10^{6}$ & $9.26 \times 10^{6}$ & $8.37 \times 10^{6}$ \\
\hline \multicolumn{4}{|c|}{ Phaeodactyllum tricornutum } \\
\hline Blank & $4.15 \times 10^{6}$ & $4.15 \times 10^{6}$ & $4.06 \times 10^{6}$ \\
\hline Cell digestion & $3.60 \times 10^{6}$ & $3.33 \times 10^{6}$ & $2.80 \times 10^{6}$ \\
\hline \multicolumn{4}{|l|}{ Chlorella sp. } \\
\hline Blank & $1.09 \times 10^{7}$ & $1.11 \times 10^{7}$ & $1.05 \times 10^{7}$ \\
\hline Cell digestion & $8.66 \times 10^{6}$ & $8.64 \times 10^{6}$ & $8.97 \times 10^{6}$ \\
\hline \multicolumn{4}{|l|}{ Phaeocystis sp. } \\
\hline Blank & $7.17 \times 10^{5}$ & $5.45 \times 10^{5}$ & $4.42 \times 10^{5}$ \\
\hline Cell digestion & $3.90 \times 10^{5}$ & $4.17 \times 10^{5}$ & $3.10 \times 10^{5}$ \\
\hline \multicolumn{4}{|l|}{ Heterocapsa sp. } \\
\hline Blank & $1.47 \times 10^{5}$ & $1.41 \times 10^{5}$ & $1.24 \times 10^{5}$ \\
\hline Cell digestion & $1.13 \times 10^{5}$ & $1.26 \times 10^{5}$ & $1.01 \times 10^{5}$ \\
\hline \multicolumn{4}{|l|}{ Dunaliella sp. } \\
\hline Blank & $1.57 \times 10^{6}$ & $1.98 \times 10^{6}$ & $1.79 \times 10^{6}$ \\
\hline Cell digestion & $1.21 \times 10^{6}$ & $1.41 \times 10^{6}$ & $1.61 \times 10^{6}$ \\
\hline \multicolumn{4}{|l|}{ Thalassiosira sp. } \\
\hline Blank & $1.26 \times 10^{5}$ & $1.27 \times 10^{5}$ & $1.28 \times 10^{5}$ \\
\hline Cell digestion & $9.21 \times 10^{4}$ & $8.58 \times 10^{4}$ & $1.06 \times 10^{5}$ \\
\hline
\end{tabular}

cells) was stable and independent of the incubation time for the period tested ( 45 to $135 \mathrm{~min}$, Table 2), indicating $45 \mathrm{~min}$ to be sufficient for the effective digestion of death cells for all seven species for which time effects were tested. The digestion procedure was also more effective at $37^{\circ} \mathrm{C}$, the standard temperature recommended for the method (Darzynkiewicz et al. 1994), than at $20^{\circ} \mathrm{C}$, as indicated by the lower percent of dead cells digested at $20^{\circ} \mathrm{C}$ as compared to those digested at $37^{\circ} \mathrm{C}$ for all seven species tested (Table 3). The cell concentration remaining after the digestion decreased asymptotically with increasing enzyme concentration to

Table 3. The percent of digested cells (mean \pm SE) in samples of cultures of seven phytoplankton species derived from enzyme digestion assays incubated at $37^{\circ} \mathrm{C}$ (standard assay temperature) versus $20^{\circ} \mathrm{C}$.

\begin{tabular}{lcc}
\hline \hline & $\begin{array}{c}37^{\circ} \mathrm{C} \\
(\% \text { cells } \\
\text { Species }\end{array}$ & $\begin{array}{c}20^{\circ} \mathrm{C} \\
(\% \text { cells } \\
\text { digested })\end{array}$ \\
\hline Synechococcus sp. & $39.5 \pm 4.5$ & $37 \pm 2.5$ \\
Phaeodactyllum tricornutum & $14.5 \pm 1.3$ & $10 \pm 6$ \\
Chlorella sp. & $20.5 \pm 7.5$ & $8.5 \pm 0.3$ \\
Phaeocystis sp. & $33.8 \pm 0.8$ & $19 \pm 6$ \\
Heterocapsa sp. & $15.4 \pm 9$ & $5.4 \pm 2.6$ \\
Dunaliella sp. & $45 \pm 7.1$ & $33 \pm 2$ \\
Thalassiosira sp. & $25.5 \pm 0.5$ & $16.9 \pm 6$ \\
\hline
\end{tabular}




\section{Trypsin (mg ml-1 $)$}
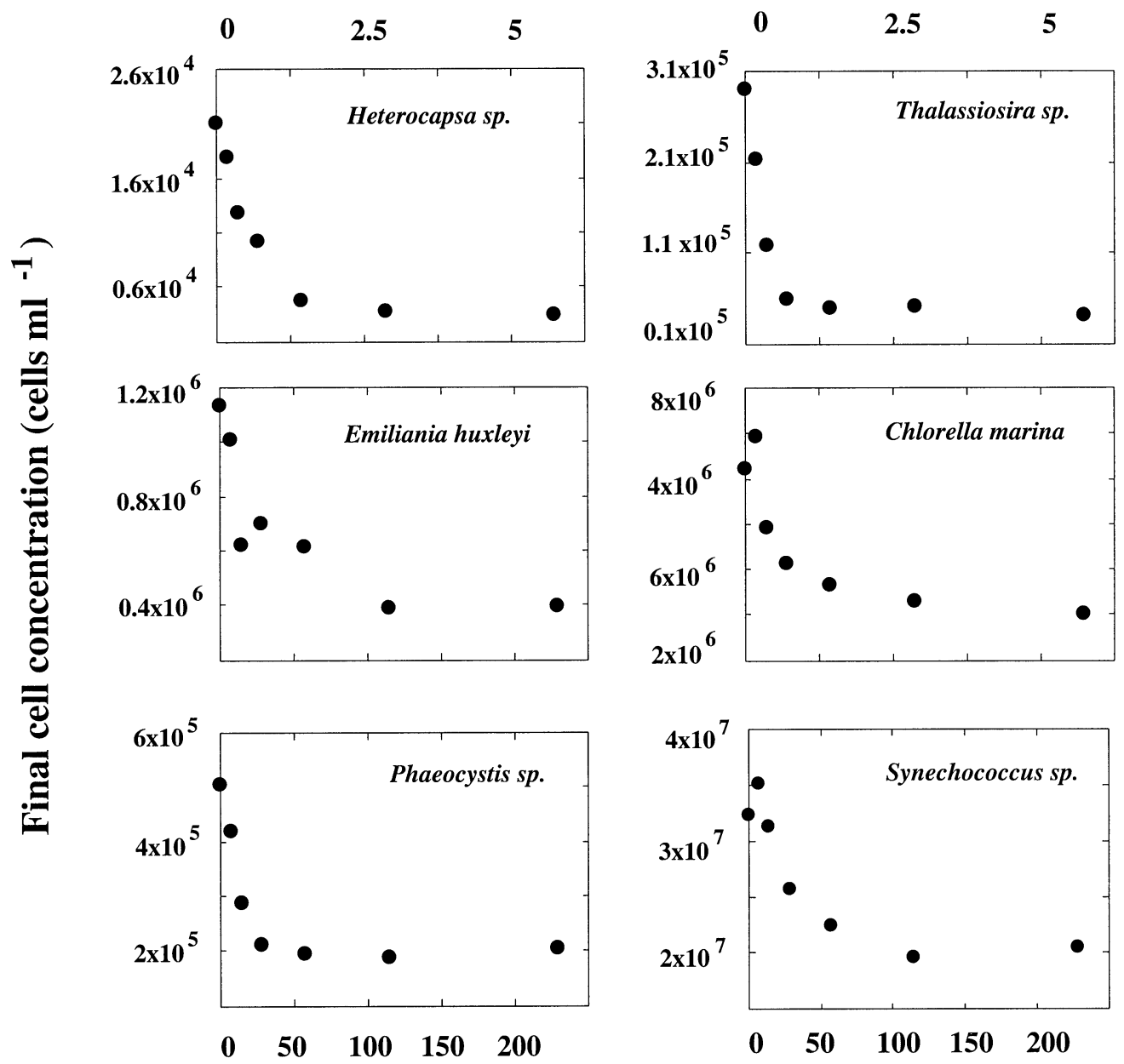

\section{DNAse $\left(\mu \mathrm{g} \mathrm{ml}^{-1}\right)$}

Fig. 2. The effect of a variable concentration of the enzymes (DNAse I and Trypsin) on the number of living cells remaining after the cell digestion assay in samples from the stationary phase of different phytoplankton species growing in cultures.

reach a plateau at $>2.5 \mathrm{mg}$ Trypsin $\mathrm{ml}^{-1}$ and $>100 \mu \mathrm{g}$ DNAse $\mathrm{ml}^{-1}$ (Fig. 2). The concentration of the enzymes at which the asymptotic final cell concentration was observed was somewhat lower when the sample was diluted (e.g., Phaeocystis sp.) or the total number of cells in the assay was lower. Therefore, final concentrations of DNAse I and Trypsin in excess of $100 \mu \mathrm{g} \mathrm{ml}^{-1}$ and $2.5 \mathrm{mg} \mathrm{ml}^{-1}$, respectively, were used thereafter. The enzyme concentrations may be, however, more diluted when applying the method in natural samples, since the abundance of phytoplankton cells in marine waters is lower than that in the cultures used here.

The red chlorophyll autofluorescence signal, as well as the side and forward scattering and green and orange fluorescence emissions, of the cells tested using flow cytometry (Phaeocystis sp., Synechococcus sp., and Prochlorococcus marina) did not change, relative to the blank samples, after the enzymatic digestion, allowing the unambiguous identification of the populations remaining after enzymatic digestion using flow cytometry (Fig. 3). The red fluorescence and side scattering of $P$. marina cells were slightly reduced following enzymatic digestion. Yet these changes were small, and the population was still unambiguously identified (Fig. 3).

The examination of the evolution of dead cells during population growth indicated the abundance of dead cells to be very low during the exponential growth phase (Fig. 4). Dead Thalassiosira sp. cells were detected as soon as the stationary phase was attained, resulting in a reduction of cell viability to approximately $80 \%$ living cells in Thalassiosira sp. (Fig. 4). For other species the number of dead cells increased before the stationary phase was attained, with $<70 \%$ of the cells living at the stationary phase (Fig. 4).

Phytoplankton cell viability in natural phytoplankton communities at the NW Mediterranean littoral-The variability 
Blank
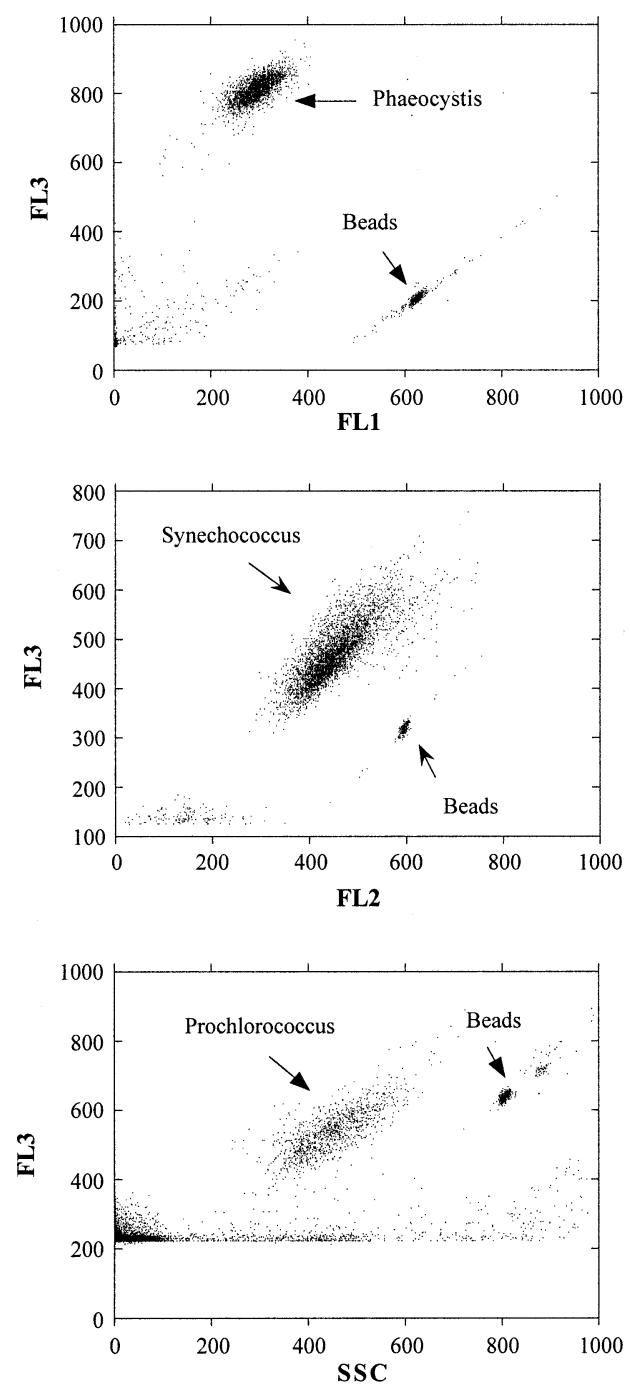

Cell digestion assay
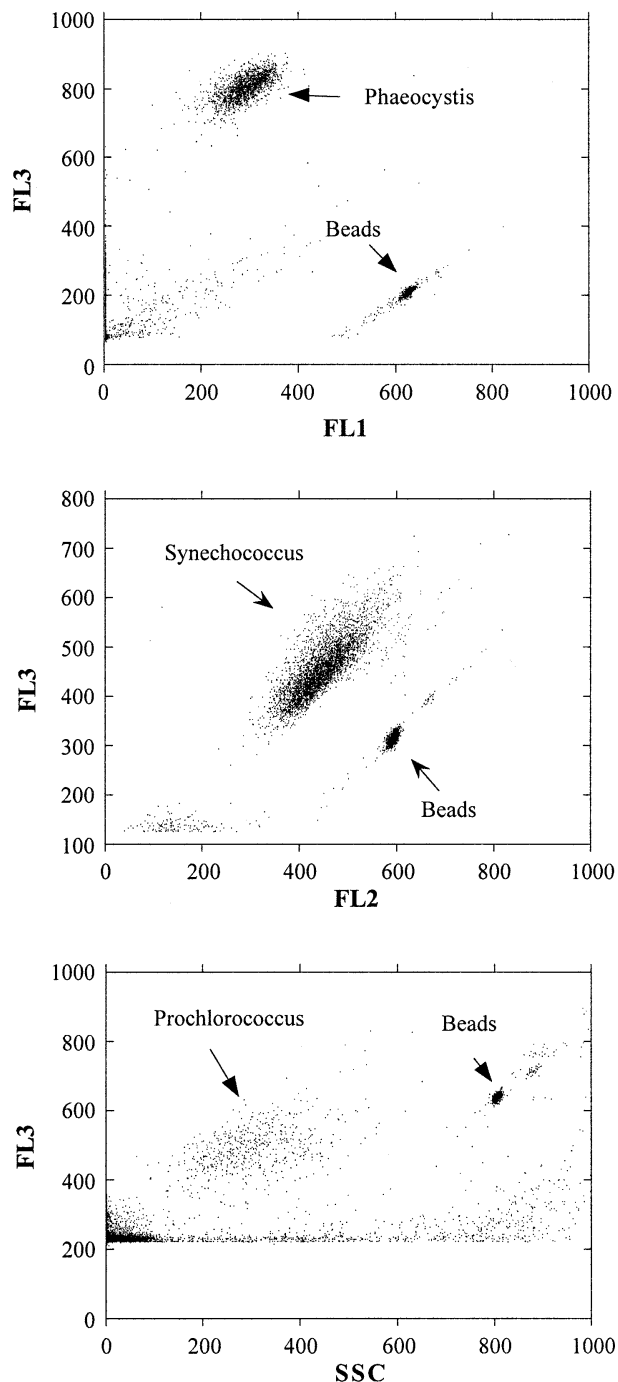

Fig. 3. Flow cytometer signals from cultures of Prochlorococcus marina, Phaeocystis sp., and Synechococcus sp. obtained in blank samples compared to the signals of the living cells remaining after the enzymatic digestion assay. Axes are expressed in arbitrary units and represented red (FL3), green (FL1) and orange (FL2) fluorescence and side scattering (SSC). High-green fluorescent $1 \mu \mathrm{m}$ diameter beads were added to the samples for cell abundance quantification.

in phytoplankton abundance, as $\mathrm{Chl} a$ concentration, during 1998 was consistent with the seasonal variability previously described for the Bay of Blanes (Mura et al. 1996; Agustí and Duarte 2000), with the lower Chl $a$ concentration observed in summer and the highest values during winter (Fig. 5). Chl $a$ concentrations decreased progressively after the winter bloom observed in February and reached the minimum values in July (monthly average $0.1 \mathrm{mg} \mathrm{m}^{-3}$ ). In August, however, there was an increase in Chl $a$ concentration (Fig. 5). The Chl $a$ concentration increased in the fall, when the surface temperatures decreased as a result of water column mixing (Fig. 5). Monthly averaged phytoplankton lysis rates varied from a minimum of $0.03 \mathrm{~d}^{-1}$ in January to a maximum of $1.2 \mathrm{~d}^{-1}$ in July. Phytoplankton lysis rates showed a seasonal pattern characterized by low values in winter (January and February, Fig. 5). An important increase in phytoplankton lysis rates was observed in March (maximum of $0.6 \mathrm{~d}^{-1}$ ), following the phytoplankton bloom of February (Fig. 5), and increased considerably during the summer, with the highest rates observed in July $\left(1.2 \mathrm{~d}^{-1}\right)$, decreasing to $0.13 \mathrm{~d}^{-1}$ by November.

Phytoplankton community structure varied greatly from June to November, the period when phytoplankton cell viability was examined. Diatoms, dominated by the genera Chaetoceros, Pseudonitzschia, and Leptocylindrus, comprised an important proportion of the phytoplankton biomass at both the beginning of summer and the fall (Fig. 6). In June, the phytoplankton community was dominated by diatoms and picocyanobacteria (50\% and $42 \%$ of total phytoplankton biovolume, respectively, Fig. 6). Cyanobacteria 
Thalassiosira sp.
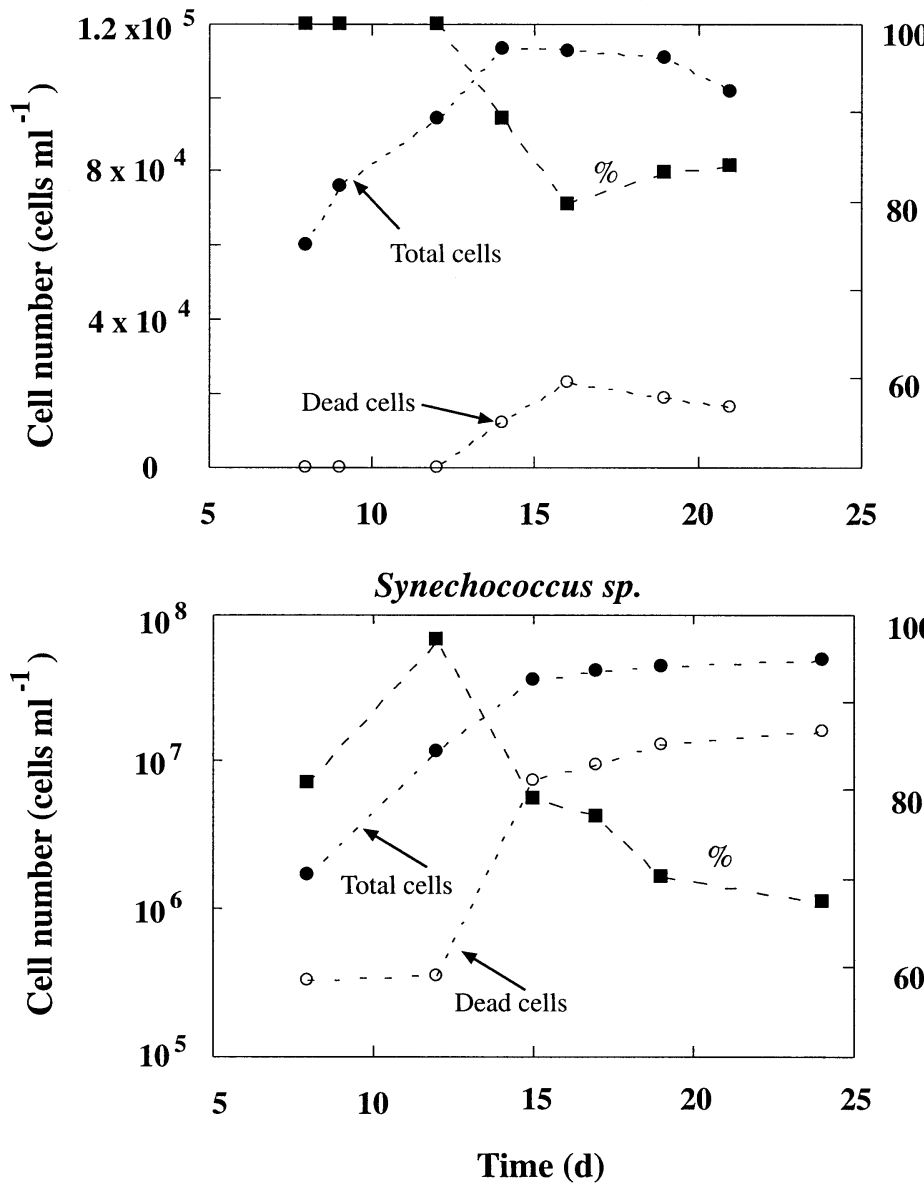

Phaeocystis sp.

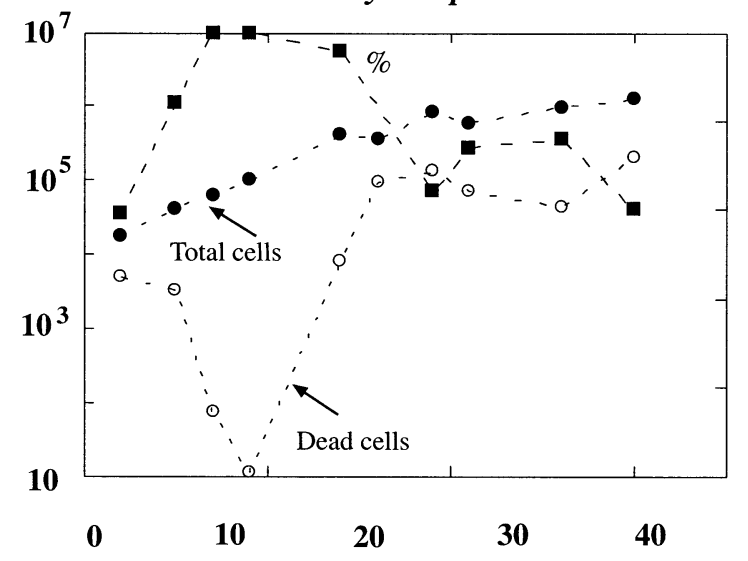

100

80 突

60

100
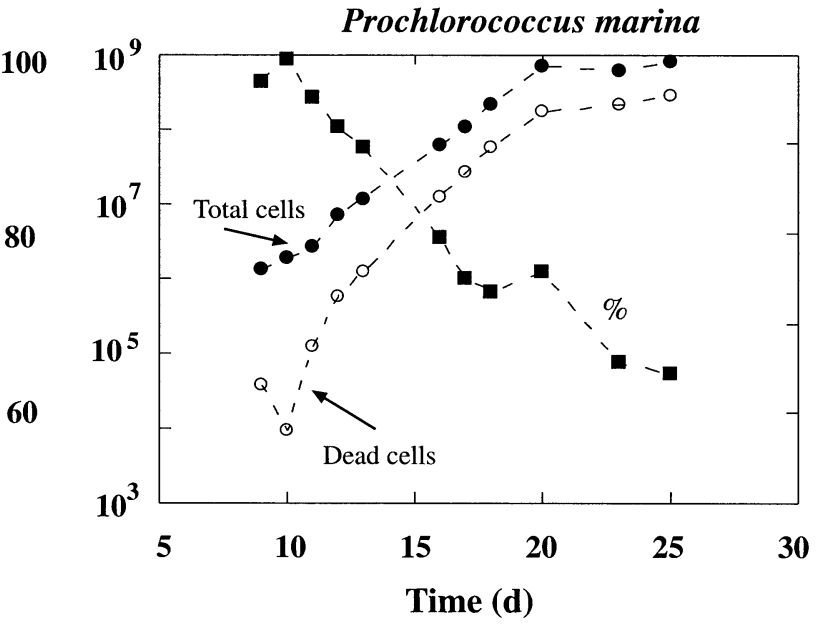

Fig. 4. Total cell abundance (solid circles), percent of living cells (cell digestion assay, solid squares), and the calculated number of dead cells (empty circles) during the exponential and stationary phases of cultures of Thalassiosira sp., Phaeocystis sp., Synechococcus sp., and Prochlorococcus marina (CCMP 1378).

(Synechococcus sp.) dominated the phytoplankton biovolume during July and August, when they comprised 72\% and $74 \%$ of the total phytoplankton biovolume, respectively (Fig. 6 ), and still represented an important proportion of the phytoplankton community during the fall (Fig. 6). The contribution of eukaryotic picophytoplankton to total phytoplankton biovolume was generally small, showing the highest contribution in July (12\% of total biovolume, Fig. 6). Other groups, as autotrophic dinoflagellates and nanoflagellates, were present but generally had a moderate contribution to total phytoplankton biovolume. Dinoflagellates were more abundant in July and October, contributing 9 and $8 \%$ of the total phytoplankton biomass, respectively, and nanoflagellates were absent at the beginning of the summer, but represented $20 \%$ of the total phytoplankton biovolume in November (Fig. 6).

The percentage of living cells varied greatly among phytoplankton groups from June to November. The percentage of dead eukaryotic picophytoplankton cells was high at the beginning of the summer (June and July), when living cells comprised only $25 \%$ of the population. However the percentage of living cells increased to $50 \%$ by the end of summer and beginning of the fall (Fig. 7). Dinoflagellate pop- ulations showed a high percentage ( $>80 \%$ ) of living cells in July and October, when they were most abundant, and in November the populations were composed of $100 \%$ living cells. The percentage of living nanoflagellate cells was always $>70 \%$ of the population during the study period, reaching 100\% living cells in August and November (Fig. 7). The percentage of living cyanobacteria (Synechococcus sp.) cells was small at the beginning of the summer ( $31 \%$ in June, Fig. 7) and increased with time to reach $100 \%$ living cells in October. However, this percentage decreased to $80 \%$ in November (Fig. 7). The percentage of living diatom cells was low during the summer, with an average of $33 \%$ in June and July, increasing subsequently to an average of $47 \%$ living cells in August-October, and reaching 81\% living cells by November (Fig. 7).

\section{Discussion}

The enzymatic digestion method was successfully applied as a probe of cell viability for a variety of phytoplankton species, including eukaryotic (diatoms, prymnesiophycea, chlorophytes) and procaryotic (Prochlorococcus sp. and Synechococcus sp.) species. Although the successful applica- 

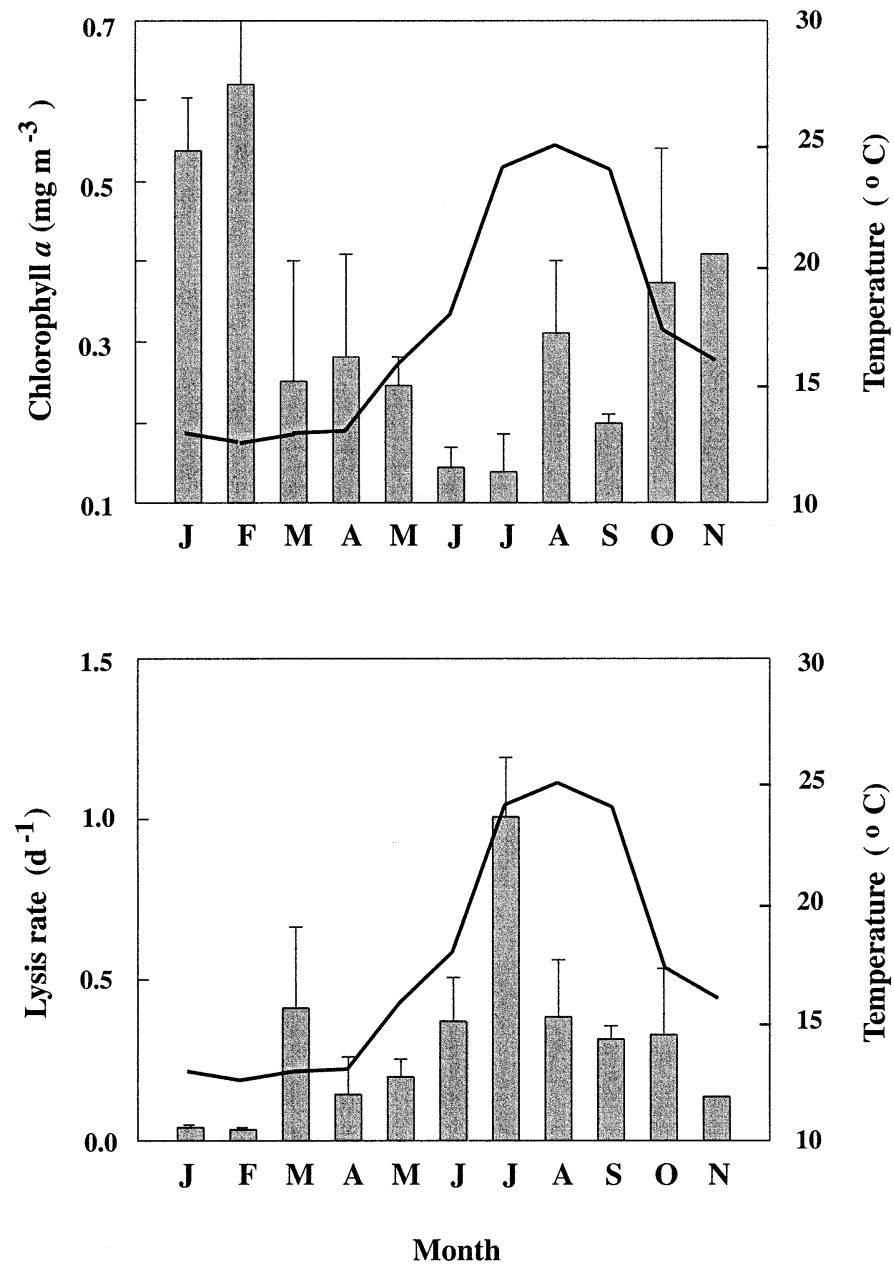

Fig. 5. The evolution of monthly averaged Chl $a$ concentration and phytoplankton lysis rates during 1998 in the Bay of Blanes (NW Mediterranean littoral). The solid line represented the evolution of monthly averaged seawater (surface) temperature. Error bars represent \pm 1 standard error.

tion of the method to this widely diverse set of species is encouraging, further tests to encompass a larger number of species should be conducted to test the universality of the method. The enzymatic cell digestion method discriminates living from dead cells on the basis of the increased permeability of membranes of dead cells. Identification of altered membrane properties as the key event leading to cell necrosis prompted the development of membrane permeability tests to identify dead or compromised cells (Wyllie et al. 1980; Ellis et al. 1991; Darzynkiewicz et al. 1994). Healthy phytoplankton cells, with intact membranes, remained unaffected by exposure to the enzyme cocktail (DNAse I and Trypsin), whereas cells with increased membrane permeability could not prevent enzymatic invasion of their cytoplasm, resulting in the destruction (digestion) of the cells (Darzynkiewicz et al. 1994). The digestion of dead phytoplankton cells by the enzyme cocktail was complete, consistent with observations from previous applications of the method to other cell types (Darzynkiewicz et al. 1994). The optical and fluorescent signals of living cells (i.e., those re- maining following the enzyme digestion) were unaffected by the exposure to the enzyme cocktail, which allowed the observation of cells using transmitted light and fluorescence (microscopy or flow cytometry) methods.

The fraction of dead cells increased from low values during the exponential growth phase to comprise an important fraction of the phytoplankton populations at the stationary phase, consistent with results obtained using vital stains (Selvin et al. 1989; Myklestad 2000), which indicates that growth conditions-resulting in exponential or stationary dynamics - affect phytoplankton cell mortality (e.g., Lee and Rhee 1997; Jochem 1999). Yet the fraction of dead cells at the stationary phase differed substantially among the species examined, which suggests that the dynamics of cell death may vary between phytoplankton species.

The enzymatic cell digestion method yielded comparable results to those obtained using the fluorescent vital stain FDA, a cell membrane permeability probe used to separate living from dead cells in a range of cell types, including phytoplankton (Widholm 1972; Söderström 1977; Selvin et al. 1989; Darzynkiewicz et al. 1994; Jochem 1999). The agreement was excellent provided that differences among the results derived from the application of different cell membrane permeability tests were expected (e.g., Joux and Lebaron 2000). Although cell membrane permeability, which determines the inclusion/extrusion of the substance used in the test, is the primary process tested by vital probes, the secondary processes that regulate the intracellular reaction of the substance (i.e., fluorescence yield depends on the intracellular esterase activity for FDA, DNA content and state for other stains, etc.) may introduce variability in the results obtained with different probes. The consistency found in the results obtained from the cell digestion method and the FDA stain indicated, however, that the secondary processes involved did not introduce any bias in the estimates of living cells.

Use of vital stains, however, present a number of problems, particularly when applied to phytoplankton, which render the cell digestion method proposed here a superior probe of phytoplankton viability. Vital stains often yield a gradient of staining intensity within the cells (Gasol and del Giorgio 2000), which introduces ambiguity in the separation between positively (living) and negatively (dead) stained cells (Gasol and del Giorgio 2000). Some of the species tested (Table 1) showed FDA staining problems that precluded use of this stain. Such problems are not restricted to FDA. For instance, the vital stain Calcein-AM, which like FDA is a substrate for esterases, has been shown to work efficiently in mammal cells and is described to have higher staining efficiency than FDA since it is less sensitive to intracellular $\mathrm{pH}$ and has less cell leakage (Haugland 1998). However, only Synechococcus sp. cells showed positive staining with Calcein-AM, among the different species tested here (Agustí unpubl. data). Even in this species, a strong background fluorescence was observed, resulting in large counting errors even at very low stain concentrations. Stains for dead cells often yield red fluorescence in dead cells (e.g., PI, propidium iodine, Darzynkiewicz et al. 1994, and BacLight staining kit, Lee and Rhee 1997), which is confounded with the natural red fluo- 


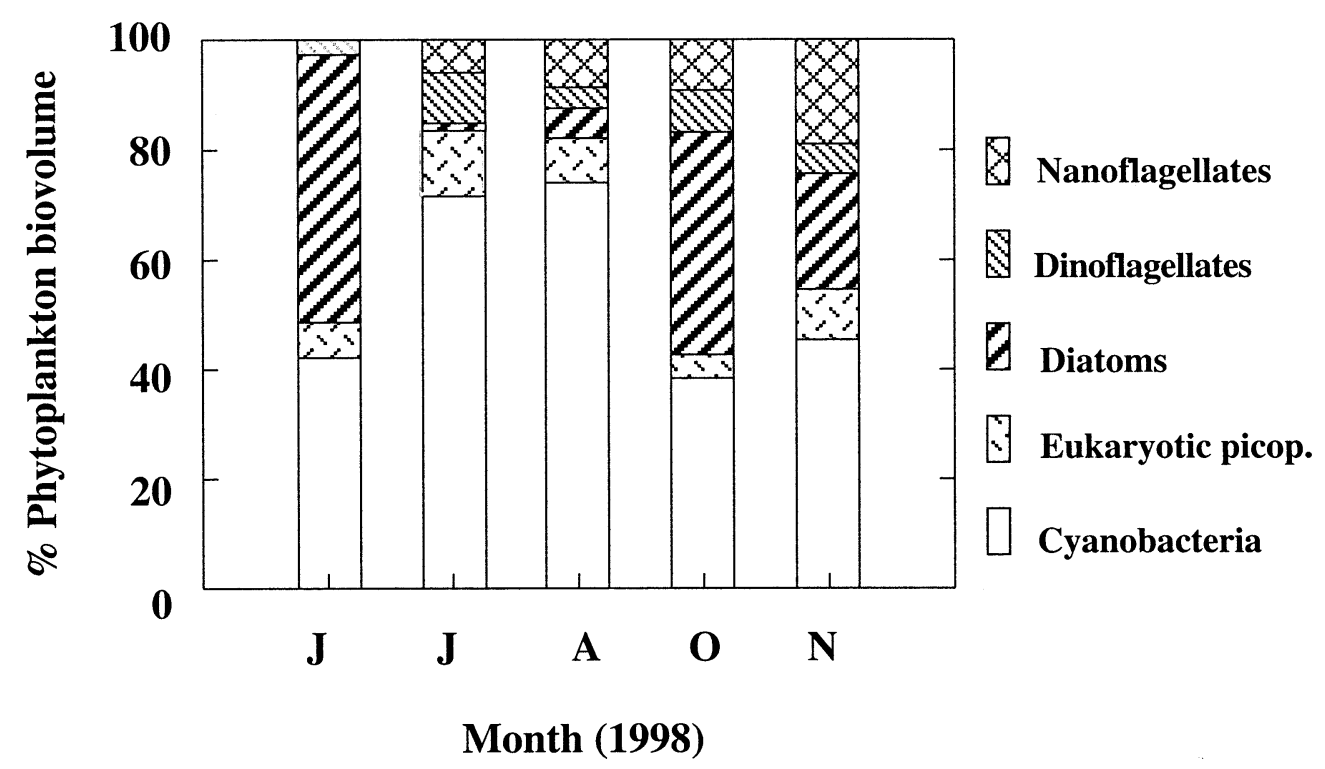

Fig. 6. Phytoplankton community composition in the Bay of Blanes in samples from summer and fall of 1998 .

rescence (from Chl $a$ ) of phytoplankton cells, except when used with cyanobacteria (Lee and Rhee 1997), whose natural orange-yellow fluorescence does not interfere with the red color of dead cells stained by the kit. In contrast to the many problems of vital stains, the enzymatic cell digestion method tested here is free of ambiguity, since cells are either totally digested out or remain intact; it does not involve fluorescence signals that may interfere with natural fluorescence of phytoplankton, and the resulting cell suspensions can be examined under transmitted light microscopy, thereby readily

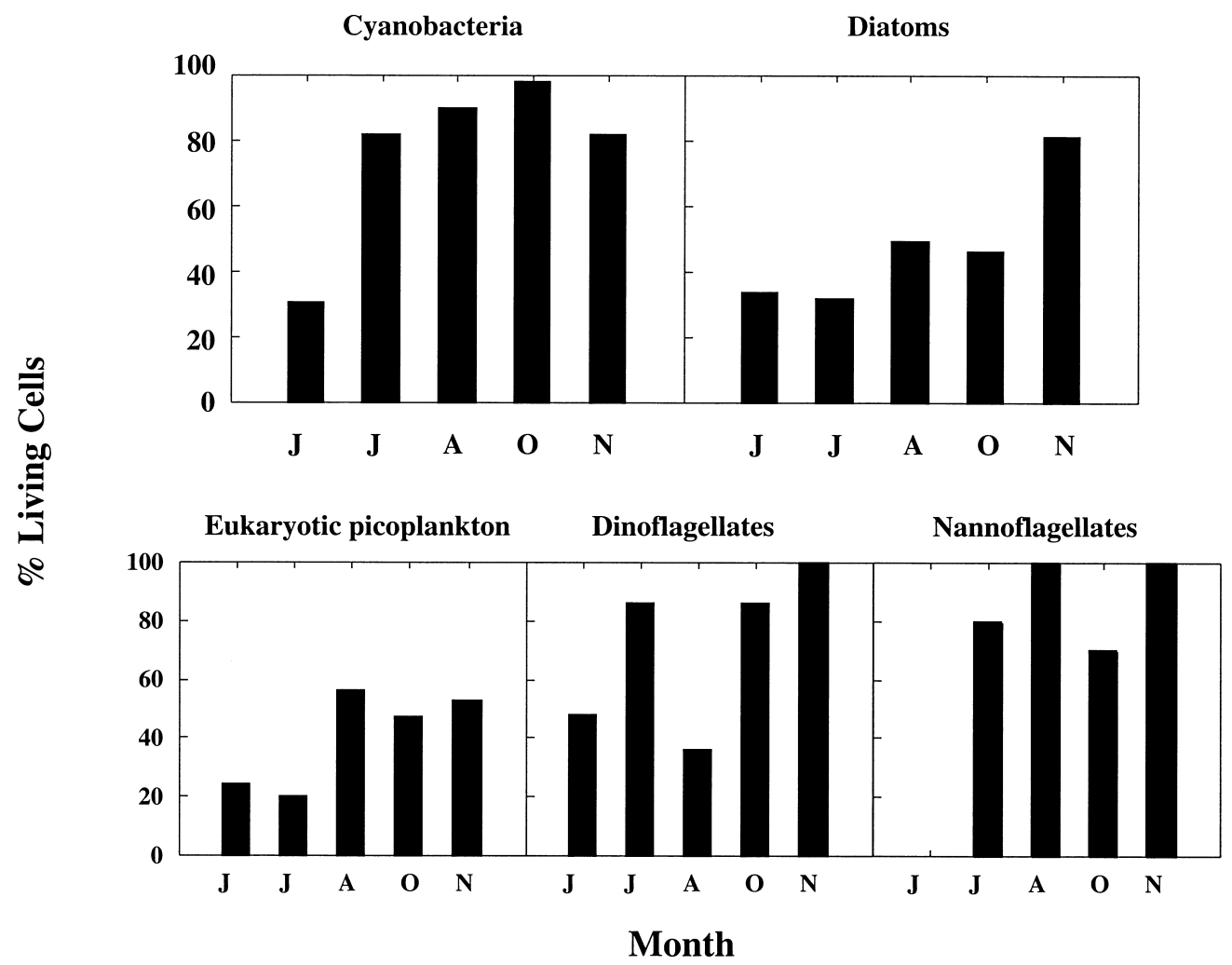

Fig. 7. The changes in the percentage of living cells (cell digestion assay) of the different groups conforming the phytoplankton community in the NW Mediterranean littoral (Bay of Blanes) during the summer and fall of 1998. 
allowing the taxonomic identification of living and dead cells.

The use of the enzymatic cell digestion method to study the dynamics of cell viability in a mixed phytoplankton community in the Blanes Bay (NW Mediterranean littoral) showed an important variability in the percentage of living cells both in time and among algal groups. The seasonal variability of the phytoplankton community observed during the study was similar to that previously described for Blanes Bay, with a late winter bloom and secondary blooms in spring, summer, and fall (Mura et al. 1996; Duarte et al. 1999; Agustí and Duarte 2000; Satta et al. 1996). The shift in the phytoplankton community observed, from a dominance of diatoms in early summer to that of picoplankton in the summer, when dinoflagellates also developed, was also in agreement with the pattern previously described for the bay (Mura et al. 1996; Agustí and Duarte 2000). The abundance of Cyanobacteria (Synechococcus sp.) in Blanes Bay is strongly seasonal and positively correlated with water temperature (Agawin et al. 1998). The high increase in cyanobacteria cell viability, from $35 \%$ of the population in June to values close to $100 \%$ as the summer progressed, suggests that the strong relationship between cyanobacteria abundance and water temperature observed in the Blanes Bay (Agawin et al. 1998) and elsewhere (Agawin et al. 2000) may result from an increasing cell death with decreasing temperature. The dominance of living cyanobacteria cells in the summer is consistent with their reported high frequency of dividing cells and fast growth rates in summer months (Agawin et al 1998). The seasonal pattern of cyanobacteria viability was in sharp contrast to that found for diatoms, which have an important contribution to biomass throughout the year in the Blanes Bay (e.g., Mura et al. 1996). The viability of diatoms was low during summer and increased subsequently to reach $80 \%$ of living cells in the diatom population in the fall.

The seasonality in the viability of phytoplankton cells was consistent with that in growth conditions in Blanes Bay, with colder, nutrient sufficient waters in fall-winter and high vertical stability conducive to oligotrophic conditions in summer (e.g., Duarte et al. 1999; Agustí and Duarte 2000). The low viability of the different groups conforming the phytoplankton community in June coincided with the period when nutrient concentrations were lowest in the Bay. Phytoplankton viability increased by midsummer, consistent with the midsummer bloom observed in August. This bloom (dominated by Synechococcus sp.) is a common feature of the Blanes Bay (Mura et al. 1996; Duarte et al. 1999; Agustí and Duarte 2000) caused by high nutrient inputs (N and P) associated to peak tourism (Duarte et al. 1999). The recovery of high viability of diatom cells in November is related to the erosion of the thermocline that results in increased nutrient concentrations, including silicate, whose concentration is very low during the summer (Duarte, unpubl. data), possibly limiting diatom growth. Hence, these results, together with the recurrent patterns in the seasonality of phytoplankton in the Bay of Blanes (Mura et al. 1996; Duarte et al. 1999; Agustí and Duarte 2000), point to temperature and nutrient ( $\mathrm{N}$ and $\mathrm{P}$, and $\mathrm{Si}$ for diatoms) concentrations as the main determinants of cell viability in the Bay of Blanes.
The seasonal variability in the viability of phytoplankton cells in the Blanes Bay was also consistent with the seasonal patterns of phytoplankton cell lysis observed, increasing from winter to summer and decreasing by fall, similar to previously reported patterns for the Bay (Agustí and Duarte 2000), which suggests that cell death is an important determinant of the seasonal variability in both the abundance and the community structure of phytoplankton there.

The cell digestion method applied here to quantify phytoplankton cell viability has potential to provide insight on phytoplankton ecology beyond the regulation of seasonal patterns in community structure. The increase in phytoplankton membrane permeability characteristic of dead cells should result in an increased release of cellular compounds to the medium (Myklestad 2000). The capacity to detect and identify dead phytoplankton cells, with compromised membranes, in natural phytoplankton communities should, therefore, be important for the identification and understanding of the sources of dissolved organic carbon in natural pelagic communities. The removal of dead cells from the sample as a result of the enzymatic cell digestion assay should also help to examine the properties of dead versus living phytoplankton cells, such as the quantification of carbon, pigment, or other cellular contents, as well as to obtain more accurate estimates of the growth rates of living phytoplankton cells. The capacity to discriminate dead from living phytoplankton cells in natural samples provided by the enzymatic cell digestion assay demonstrated here may, therefore, open new avenues for an improved understanding of the ecology of phytoplankton communities and the processes they mediate in the ocean.

\section{References}

Agawin, N. S., C. M. Duarte, And S. Agustí. 1998. Growth and abundance of Synechococcus sp. in a Mediterranean Bay: Seasonality and relationship with temperature. Mar. Ecol. Prog. Ser. 170: $45-53$.

- $\longrightarrow$, AND $\longrightarrow$ 2000. Nutrient and temperature control of the contribution of picoplankton to phytoplankton biomass and production. Limnol. Oceanogr. 45: 591-600.

Agustí, S., AND C. M. Duarte. 2000. Strong seasonality in phytoplankton cell lysis in the NW Mediterranean littoral. Limnol. Oceanogr. 45: 940-947.

- D. Vaqué, M. Hein, J. M. Gasol, and M. Vidal. 2001. Food web structure and elemental (C, N and P) fluxes in the eastern tropical North Atlantic. Deep-Sea Res. II 48: 2295-2321.

- M. P. Satta, M. P. Mura, And E. Benavent. 1998. Dissolved esterase activity as tracer of phytoplankton lysis: Evidence of high phytoplankton lysis rates in the NW Mediterranean. Limnol. Oceanogr. 43: 1836-1849.

Baldi, F., A. Minacci, A. Saliot, L. Mejanelle, P. Mozetic, V. TurK, AND A. MALEJ. 1997. Cell lysis and release of particulate polysaccharides in extensive marine mucilage assessed by lipid biomarkers and molecular probes. Mar. Ecol. Prog. Ser. 153: 45-57.

BRUSSAARD, C. P. D., AND OTHERS. 1995. Effects of grazing, sedimentation and phytoplankton cell lysis on the structure of a coastal pelagic food web. Mar. Ecol. Prog. Ser. 123: 259-271.

DarZYNKIEWICZ, Z., X. Li, AND J. Gong. 1994. Assays of cell viability: Discrimination of cells dying by apoptosis. In Z. Dar- 
zynkiewicz, J. P. Robinson, and H. A. Crissman [eds.], Methods in cell biology. Academic.

Duarte, C. M., S. Agustí, H. Kennedy, and D. Vaqué. 1999. The Mediterranean Climate as a template for the Mediterranean marine ecosystem: The example of the northeast Spanish littoral. Prog. Oceanogr. 44: 245-270.

Ellis, R. E., J. YuAN, AND H. R. HoRvitZ. 1991. Mechanisms and functions of cell death. Annu. Rev. Cell Biol. 7: 663-698.

GAsol, J. M., AND P. A. DEL GioRgio. 2000. Using flow cytometry for counting natural planktonic bacteria and understanding the structure of planktonic bacterial communities. Sci. Mar. 64: 194-224.

Haugland, R. P. 1998. Handbook of fluorescent probes and research chemicals. Molecular Probes.

JoCHEM, F. J. 1999. Dark survival strategies in marine phytoplankton assessed by cytometric measurement of metabolic activity with fluorescein diacetate. Mar. Biol. 135: 721-728.

JouX, F., AND P. LEBARON. 2000. Use of fluorescent probes to assess physiological functions of bacteria at single-cell level. Microb. Infect. 2: 1523-1535.

Kirchman, D. L. 1999. Phytoplankton death in the sea. Nature 398: 293-294.

KNOECHEL, R., AND J. KALFF. 1978. An in situ study of the productivity and population dynamics of five freshwater planktonic diatom species. Limnol. Oceanogr. 23: 195-218.

LeE, D. Y., AND G. Y. RheE. 1997. Kinetics of cell death in the cyanobacterium Anabaena flos-aquae and the production of dissolved organic carbon. J. Phycol. 33: 991-998.

Mura, M. P., S. Agustí, J. Cebrián, And M. P. Satta. 1996. Seasonal variability of phytoplankton biomass and community composition off Blanes Bay (1992-1994). Public. Espec. Ins. Esp. Oceanogr. 22: 23-30.
MyKLESTAD, S. M. 2000. Dissolved organic carbon from phytoplankton, p. 111-148. In P. J. Wangersky [ed.], Marine chemistry. Springer.

Rotman, B., AND B. W. PAPERMASTer. 1966. Membrane properties of living mammalian cells as studied by enzymatic hydrolysis of fluorogenic esters. Proc. Natl. Acad. Sci. U.S.A. 55: 134141.

Satta, M. P., S. Agustí, M. P. Mura, and C. M. Duarte. 1996. Seasonal variability of planktonic gross primary production off Blanes Bay (March 1992-March 1994). Publ. Espec. Inst. Esp. Oceanogr. 22: 31-38.

Selvin, R., B. Reguera, I. Bravo, and C. M. Yentsch. 1989. Use of fluorescein diacetate (FDA) as a single-cell probe of metabolic activity in dinoflagellate cultures. Biol. Oceanogr. 6: $505-511$.

SöDERSTRÖM, B. E. 1977. Vital staining of fungi in pure cultures and in soil with fluorescein diacetate. Soil Biol. Biochem. 9: $59-63$.

van Boekel, W. H. M., F. C. Hansen, R. Riegman, and R. P. M. BAK. 1992. Lysis-induced decline of a Phaeocystis spring bloom and coupling with the microbial food web. Mar. Ecol. Prog. Ser. 81: 269-276.

Veldhuis, M. J. W., AND G. W. KraAy. 2000. Application of flow cytometry in marine phytoplankton research: Current applications and future perspectives. Sci. Mar. 64: 121-134.

WidHOLM, J. M. 1972. The use of fluorescein diacetate and phenosafranine for determining viability of cultured plant cells. Stain Technol. 47: 189-194.

Wyllie, A. H., J. F. R. KerR, AND A. R. Currie. 1980. Cell death: The significance of apoptosis. Int. Rev. Cytol. 68: 251-306.

Received: 13 November 2001

Amended: 28 January 2002

Accepted: 13 February 2002 